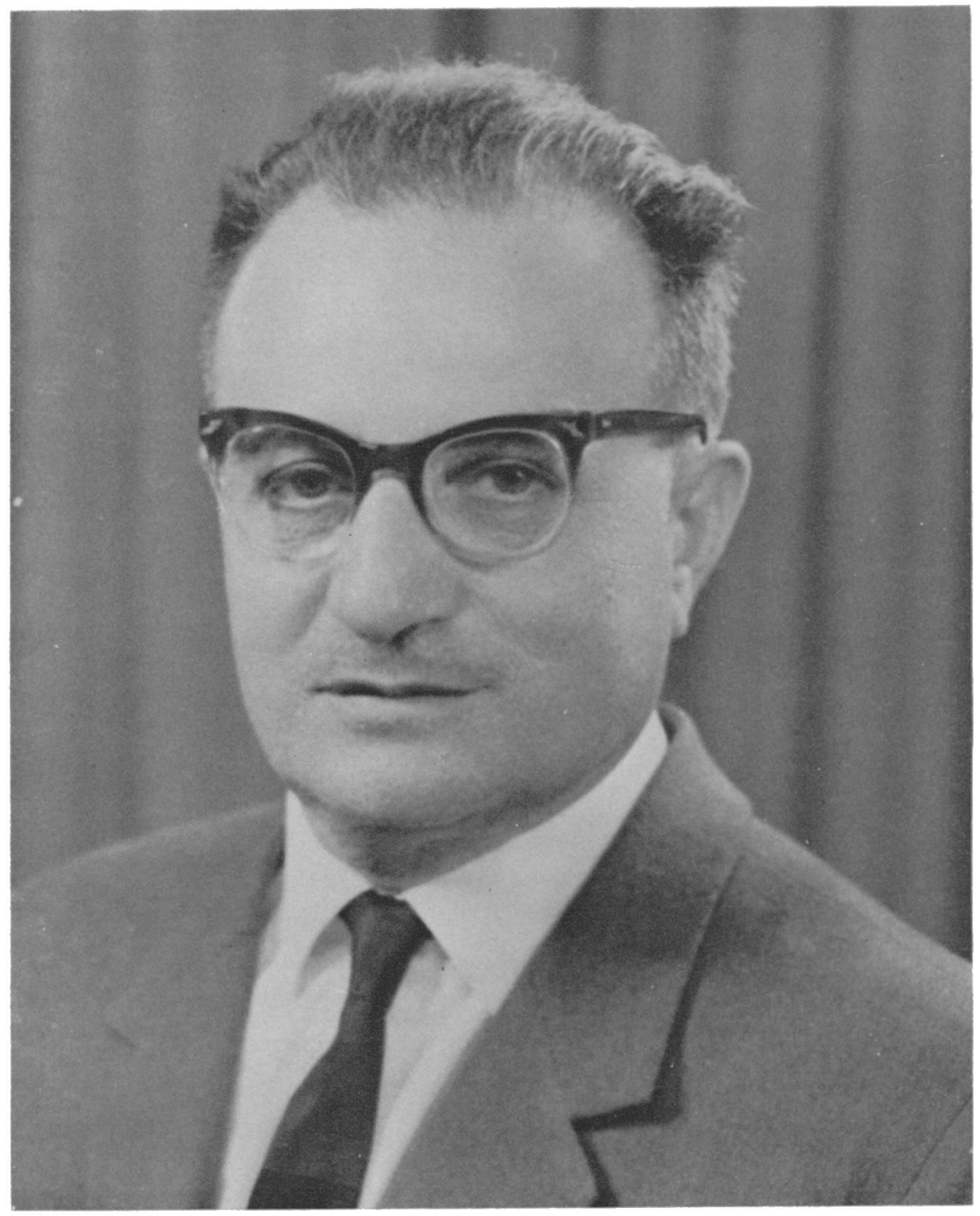




\section{PROFESSOR FUAD SAFAR}

It is with deep regret that we record the death of Professor Fuad Safar in a motor accident when on duty travelling to the Jebel Hamrin where he was about to inspect a series of rescue excavations.

Fuad will be grievously missed not only by the Department of Antiquities in Iraq but by many friends in this country. He was an archaeologist of international repute, not only for his skill as a digger but also because of his profound learning, which sat lightly upon him. Whatever he undertook was achieved with an air of insouciance which made his successes appear all the more remarkable. Some time ago he visited this country in order to deliver, before the University of London, three lectures on his remarkable excavations at Hatra. He arrived without slides and without notes and by Herculean efforts on his part and that of friends, brought his task to a happy conclusion.

He gained fame on many important enterprises including the excavation of the great 'Umayyad mosque and palace at Wâsit and subsequently through the discovery of the proto-Sumerian "Painted Temple" at Tell 'Uqair (with Seton Lloyd) where the wide range of his abilities was amply displayed not only by the competence of his excavations but by his ability to examine the early inscribed tablets which were forthcoming from that site. He also, in company with Seton Lloyd, excavated Tell Hassuna and there revealed the remains of the earliest agricultural settlement then known in Iraq, probably founded in the early sixth millennium B.c.

Fuad's last series of excavations were conducted at Hatra, the capital city of an early Arab dynasty where remarkable statuary of the Parthian and subsequent Sassanian periods came to light. No greater tribute could be paid in honour of this great archaeologist than by continuing the work at Hatra where a wealth of information remains to be revealed not only in temples and palaces but in private houses which so far have hardly been touched.

For more than two decades he was the eminence grise of the Iraq Antiquities Department. Naji el-Asil, whose efforts did much for the foundations of Iraqi archaeology, depended on him consistently as did his successors. His greatest achievement is the excavation of the site of Eridu in conjunction with Seton Lloyd, an admirable partnership, and we may expect to see its fruitful results in a forthcoming publication which his friends hope will not now be long delayed.

There was a no more delightful companion than Fuad, with his whimsical and infectious sense of fun. He was generous in the aid he gave to all foreign colleagues as well as to his own, and there are many who will miss him sorely.

Max Mallowan 